\title{
Vermicomposting as an Alternative Method of Sludge Treatment
}

\section{Dariusz Boruszko'}

1 Bialystok University of Technology, Faculty of Civil Engineering and Environmental Sciences, Department of Technology in Environmental Engineering, ul. Wiejska 45a, 15-351 Białystok, Poland

e-mail: d.boruszko@pb.edu.pl

\begin{abstract}
The article presents the results of the research from several years of exploitation of the vermiculture plots located in the municipal wastewater treatment plant in Zambrów. It is the only facility in Poland where the vermicompost from municipal sewage sludge has been produced continuously since 2004 (for 16 years). The results of tests of ready-made vermicomposts conducted regularly twice a year (32 tests) were subjected to a simple statistical analysis. The vermicompost analyses of heavy metals, biogenic compounds, organic matter and selected macroelements were compared with the requirements for mineral-organic fertilizers. In terms of the heavy metals content, the highest total content was observed in the first year of plots exploitation, i.e. in 2004, when it amounted to over $1200 \mathrm{mg}^{-1} \mathrm{~kg}$ DM. The lowest sum content of heavy metals in vermicomposts, amounting to $398 \mathrm{mg}^{-1} \mathrm{~kg} \mathrm{DM}$, was recorded in 2017. The median total content of heavy metals from all observations was $821 \mathrm{mg}^{-1} \mathrm{~kg}^{-1}$ D. During the whole research period, the content of nutrients in vermicomposts was high, for nitrogen it ranged from $9.8 \mathrm{~g}^{-1} \mathrm{~kg}$ DM to $31.1 \mathrm{~g}^{-1} \mathrm{~kg}$ DM (median $14.3 \mathrm{~g}^{-1} \mathrm{~kg} \mathrm{DM}$ ), whereas for phosphorus it ranged from $2.1 \mathrm{~g}^{-1} \mathrm{~kg} \mathrm{DM}$ to $14.5 \mathrm{~g}^{-1} \mathrm{~kg}$ DM (median $5.5 \mathrm{~g}^{-1} \mathrm{~kg} \mathrm{DM}$ ). The content of organic matter in the whole several-year study period was high and ranged from 21.3\% DM to 59.0\% DM (median 33.1\% DM). The conducted research confirmed that the use of California earthworm in the process of municipal sewage sludge vermicomposting results in its good mineralization and humification, and the final product (vermicompost) may be a valuable mineral-organic fertilizer.
\end{abstract}

Keywords: vermicomposting, sewage sludge, earthworms, heavy metals

\section{INTRODUCTION}

Earthworms are organisms that participate in the circulation of organic matter in nature. Earthworms also increase the bioavailability of plant nutrients as well as ensure proper aeration and soil moisture. They play an important role in the ecosystem through their contribution to the water, carbon and nutrient cycle. Out of more than 8300 species, only a few earthworm species can be used in the process of industrial vermicomposting [Reynolds and Wetzel 2004]. In Europe, three species of earthworms are most commonly used in this process: Eisenia fetida, Eisenia andrei and Dendrobaena veneta. These three most popular species can be characterized by such features as short life cycle, high reproductive rate, low body weight and high resistance that helps them survive in hostile environment [Dominguez and Edwards 2011].
In the vermicomposting technology, the Eisenia foetita earthworm, the so-called California earthworm, is used most frequently. However, under real conditions it is difficult to speak of organic matter being processed by only one species, even if only one species was inoculated into the substrate. This species of earthworm was bred in the 1950s by scientists from California. This species lives near the surface, where the highest concentration of organic matter occurs. This allows for habitat retention and transformation of top-fed organic matter. The California earthworm is characterized by four times longer life span (up to 16 years) and twelve times higher fertility than the traditional soil-dwelling earthworms. California earthworms quickly process organic matter, can live at high density and are more resistant to temperature drops [Kostecka 1994]. A single earthworm can process several times as much organic matter as its own body weight every day. 
A study by Kostecka shows that one ton of earthworm biomass can convert one ton of sludge into vermicompost within five days [Kostecka 1995]. Vermicomposting is a combination of traditional composting and the physiological activity of earthworms. The processing of sewage sludge takes place through the activity of microorganisms occurring in the organic matter and digestive tract of earthworms and the enzymes they produce. In their digestive tract, earthworms transform organic matter into an amorphous form with a high degree of humification. During the process, the forms of nitrogen, phosphorus, potassium and calcium which are easily absorbable by plants are produced [Konopska 2011].

The first documented studies on the use of the Eisenia fetida earthworm for the processing purpose date back to 1977 [Mitchell et al. 1977]. Among the many species of earthworms, there are also those that can transform specific types of organic waste such as solid waste from the paper industry, household waste and sewage sludge into a valuable product called vermicompost [Hoornweg and Bhada-Tata 2012, Azizi et al. 2013, Butt 1993, Yadav et al. 2010, Suthar and Singh 2008]. The metabolic and enzymatic activity of earthworms supports the decomposition of organic matter [Edwards and Lofty 1977]. Many researchers point out that vermicomposting may be an interesting alternative, possibly complementing the classical process of organic waste composting [Ndegwa and Thompson 2001]. Research was also carried out on a combined method joining the processes of classical composting and vermicomposting for various organic wastes [Alidadi and Shamansouri 2005, Yadav et al. 2012].

The compost obtained during the intensive activity of farm earthworms (at high density) in organic waste is called vermicompost (also called earthworm compost, biohumus or simply earthworm fertilizer). Unlike traditionally produced compost, vermicompost has very valuable properties, which are largely dependent on the composition of the nutrient, the density of the culture, the amount of time earthworms stay in the food layers [Kostecka 1997, Walkowiak 2007]. Vermicompost is a very good natural fertilizer. The quality of the created vermicompost depends mainly on the initial composition, the content of pollutants and performed maintenance [Boruszko 2016, Bożym 2012].

Vermicopost is rich in most of the nutrients available directly to plants. These include nitrates, phosphates, calcium, potassium and magnesium. Vermicompost contains significant amounts of humic substances and microorganisms such as fungi, bacteria and actinomycetes. In contrast to the substrate from which it is produced, the finished fertiliser contains less lead, cadmium and zinc. Hazardous heavy metal compounds take the form of complexes of these metals that are difficult to absorb by plants.

The produced biohumus is extremely effective in gardening. It is a valuable addition to the plant substrate. It can be used for most garden and agricultural plants. When used as a soil additive, it creates a perfect substrate for domestic plants; when mixed with water, it is suitable for watering lawns, and when scattered, it supports their growth and maintenance [Konopska 2011].

Vermiculture can be applied in a wide variety of ways [Mitchell et al. 1977, Hoornweg and Bhada-Tata 2012, Yadav et al. 2010, Bhatnagar et al. 2016, Azizi et al. 2013]:

- production of high-quality fertilizer (vermicompost) from organic matter, used on large areas of crops as a supplement to mineral fertilization and as the only fertilizer for small garden crops,

- production of feed for farm animals (e.g. fish, poultry, pigs),

- capturing of e.g. heavy metals from degraded soils,

- obtaining the compounds used in the cosmetics industry, medicine and pharmacy from earthworm bodies.

Vermiculture plays an extremely important role in the soil biology. In addition to the conversion of organic matter into fertiliser, the earthworm population participates in the soil-forming processes. It influences the development, formation and physical properties of these processes.

\section{FIELD OF STUDY AND EXPERIMENTAL METHODS}

The Zambrów municipal wastewater treatment plant is the only one in Poland that uses only natural methods to process sewage sludge. During the vegetation season, i.e. from March to October, the sewage sludge generated during the wastewater treatment is processed in reed lagoons and vermicompost plots. The process of composting with the use of Eisenia fetida 
earthworms started in 2003. The first vermicompost was obtained in 2004 and since then the research has been carried out continuously. In order to ensure optimal vermicomposting conditions, among other things, a layer of $15-20 \mathrm{~cm}$ of sawdust is applied to the bottom of the plots to ensure a proper $\mathrm{C} / \mathrm{N}$ ratio, which is then filled with sewage sludge that is initially thickened in the lagoon during the winter season. Sedimentary plots currently occupy an area of approximately $10000 \mathrm{~m}^{2}$ and are divided into several tens of plots divided by so-called "dens" to which earthworms migrate after processing during the growing season of sewage sludge. The wastewater treatment plant in Zambrów produces about 600 tons of sewage sludge annually, of which about $40 \%$ is directed to vermicomposting plots.

The research on ready-made vermicompost was conducted in the period of 16 years from 2004 to 2019. In vermicomposts, the content of heavy metals $(\mathrm{Pb}, \mathrm{Hg}, \mathrm{Cu}, \mathrm{Cd}, \mathrm{Ni}, \mathrm{Zn}, \mathrm{Cr})$, fertilizing elements $(\mathrm{N}, \mathrm{P})$, macroelements $(\mathrm{Ca}$, $\mathrm{Mg}$ ), dry matter, organic substances and $\mathrm{pH}$ was determined. The research was conducted in the Department of Technology in Environmental Engineering of the Białystok University of Technology.

Dry matter, organic matter, TOC, TC, Nitrogen, Phosphorus, micro- and macroelements were determined by using standard methods [Standard Methods....2005].

\section{RESULTS AND DISCUSSION}

The results of the research on the vermicompost produced over 16 years in treatment plant in Zambrów were presented below in figures. The results of vermicompost tests obtained in the period of 16 years of research were statistically processed with the Statistica program. Figure 1 shows the results of the research concerning the content of heavy metals in vermicompost (median, min. and max. $25-75 \%$ percent).

The results of the tests concerning the content of heavy metals in vermicomposts in the years 2004-2019 show high variability and dispersion of the recorded content individually for particular elements. The lowest content in vermicompost was recorded for two microelements, i.e. mercury from $0.25 \mathrm{mg}^{-1} \mathrm{~kg} \mathrm{DM}$ to $1.09 \mathrm{mg}^{-1} \mathrm{~kg} \mathrm{DM}$ (median $0.71 \mathrm{mg}^{-1} \mathrm{~kg} \mathrm{DM}$ ) and cadmium from $1.06 \mathrm{mg}^{-1} \mathrm{~kg}$ DM to $3.50 \mathrm{mg}^{-1} \mathrm{~kg} \mathrm{DM}^{-}$(median $\left.1.88 \mathrm{mg}^{-1} \mathrm{~kg} \mathrm{DM}\right)$. In vermicompost, zinc was the most abundant in the range from $301 \mathrm{mg}^{-1} \mathrm{~kg} \mathrm{DM}$ to $983 \mathrm{mg}^{-1} \mathrm{~kg}$ DM (median $645 \mathrm{mg}^{-1} \mathrm{~kg} \mathrm{DM}$ ). Zinc was also the element which was characterized by the highest dispersion and variability of its content in vermicompost during the 16 years of research. Chromium was the most stable element; its content in vermicompost was characterized by the smallest dispersion. The total content of the analyzed heavy metals was the highest in 2004 and reached over $1200 \mathrm{mg}^{-1} \mathrm{~kg}$ of dry mss, whereas the lowest content was analyzed in 2017 at $398 \mathrm{mg}^{-1} \mathrm{~kg}$ DM (median $821 \mathrm{mg}^{-1} \mathrm{~kg} \mathrm{DM}$ ). The content of heavy metals in vermicompost was significantly lower in the whole period of research in relation to the legal regulations in force in Poland concerning the municipal sewage sludge used for agricultural purposes and for mineral-organic fertilizers.

Figures 2 and 3 present the research results for selected macroelements and fertilizing elements as well as vermicompost weight analysis in particular years.

Vermicomposting is one of the low-cost methods for processing the sewage sludge to produce a high-quality product for use in agriculture [Riggle D et al. 1994]. The test results analysis of vermicompost from the wastewater treatment plant in Zambrów concerning macroelements allows us to conclude that their content is relatively high. Among the examined vermicompost, nitrogen from 9.8 to $9.8 \mathrm{~g}^{-1} \mathrm{~kg}$ DM to $31.1 \mathrm{~g}^{-1} \mathrm{~kg} \mathrm{DM}$ (median $14.3 \mathrm{~g}^{-1} \mathrm{~kg} \mathrm{DM}$ ) and calcium from $8.5 \mathrm{~g}^{-1} \mathrm{~kg}$ DM to $40.8 \mathrm{~g}^{-1} \mathrm{~kg} \mathrm{DM}$ (median $17.6 \mathrm{~g}^{-1} \mathrm{~kg} \mathrm{DM}$ ) were found in the highest amounts. Phosphorus from $2.1 \mathrm{~g}^{-1} \mathrm{~kg} \mathrm{DM}$ to $14.5 \mathrm{~g}^{-1} \mathrm{~kg} \mathrm{DM}$ (median $5.5 \mathrm{~g}^{-1} \mathrm{~kg} \mathrm{DM}$ ) and magnesium from $1.0 \mathrm{~g}^{-1} \mathrm{~kg}$ DM to $5.2 \mathrm{~g}^{-1} \mathrm{~kg} \mathrm{DM}$ (median $4.8 \mathrm{~g}^{-1} \mathrm{~kg} \mathrm{DM}$ ) were found in smaller amounts. Magnesium was the most stable in the period of 16 years, whereas calcium was the most variable macroelement in vermicompost. Similarly, the content of organic matter and dry matter in the studied vermicompost was characterized by high variability during the study period. Organic matter ranged from $21.3 \% \mathrm{DM}$ to $59.0 \% \mathrm{DM}$ (median 33.1\% DM), while the dry matter content ranged from $36.0 \%$ to $62.1 \%$ (median $49.1 \%$ ). $\mathrm{Ph}$ of vermicomposts varied from 5.07 to 7.02 .

The microbiological and parasitological control of vermicompost was also carried out throughout the whole research period. There was no presence of Salmonella bacteria and live 

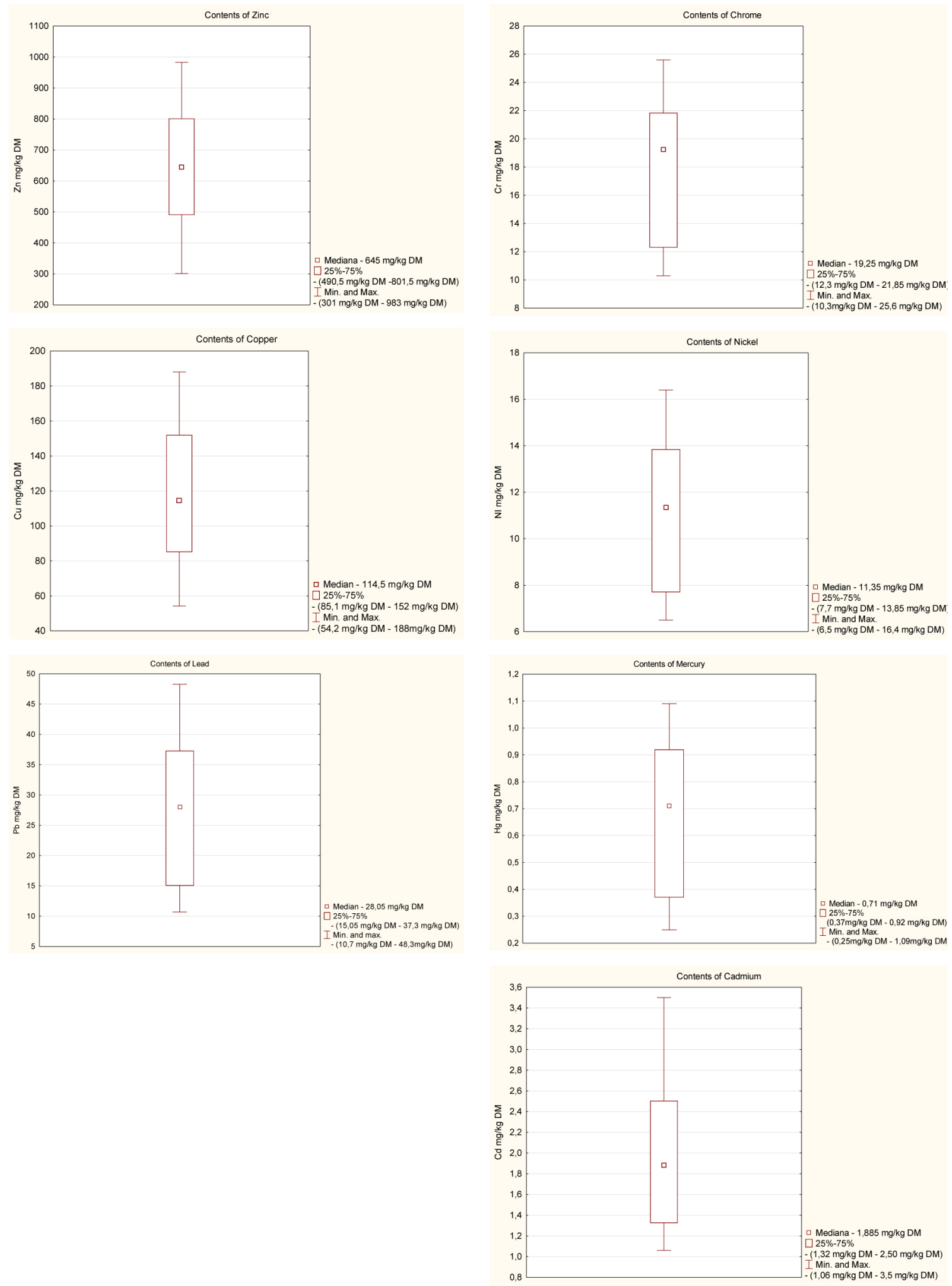

Figure 1. Changes in the content of heavy metals in vermicomposts in the period of 16 years of research

eggs of intestinal parasites: Ascaris sp., Trichuris sp., Toxocara sp. The absence of pathogenic microorganisms and invasive eggs in vermicompost from sewage sludge is also confirmed by other studies [Brown A. B et al. 1981 Boruszko and Butarewicz 2015].
The vermicomposting process may constitute an interesting alternative for the existing waste treatment strategies, mostly for small municipalities. This aerobic process of decomposition of organic matter, in which earthworms cooperate with microorganisms can lead to an important 


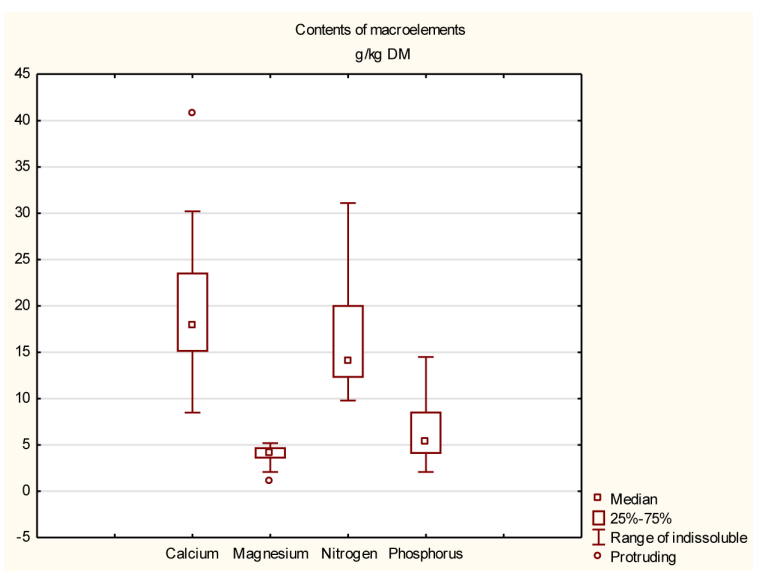

Figure 2. Contents of calcium, magnesium, total nitrogen and phosphorus on vermicopost

decrease of E. coli and Salmonella spp. (Eastman et al. 2001,), improve the physical and chemical parameters of the substrate [Kostecka 2000, Rorat et al. 2015].

The research on the quality of vermicompost from municipal sewage sludge, which has been conducted for several years, is of significant importance for its agricultural use, not only in the region of north-eastern Poland. The initial population of the Eisenia fetida earthworm, which was inoculated into the vermicompost plots in 2003, significantly changes the composition and properties of sewage sludge at the Zambrów wastewater treatment plant. The results of the research on the vermicompost from the Zambrów wastewater treatment plant from the whole research period enable to classify it as mineral-organic fertilizer. The application of concentrated earthworm populations in the processing of municipal sewage sludge into good quality vermicompost may play an important role in the recycling of sludge into the environment [Kacprzak 1994, Hatanaka 1983].

The use of California earthworms in the processing of municipal sewage sludge is also important for the accumulation of heavy metals in their bodies [Neuhauser et al. 1994, Rorat et al. 2015]. The manner and amount of accumulation of individual microelements depends on many factors, including the species of earthworm and its metabolic differences [Morgan and Morgan 1992]. Numerous studies also confirm that earthworms are considered an important factor in the biodegradation of many other hazardous and specific substances present in sewage sludge, such as PAHs [Lu and Lu 2015,Włóka et al. 2013, Boruszko 2013a].

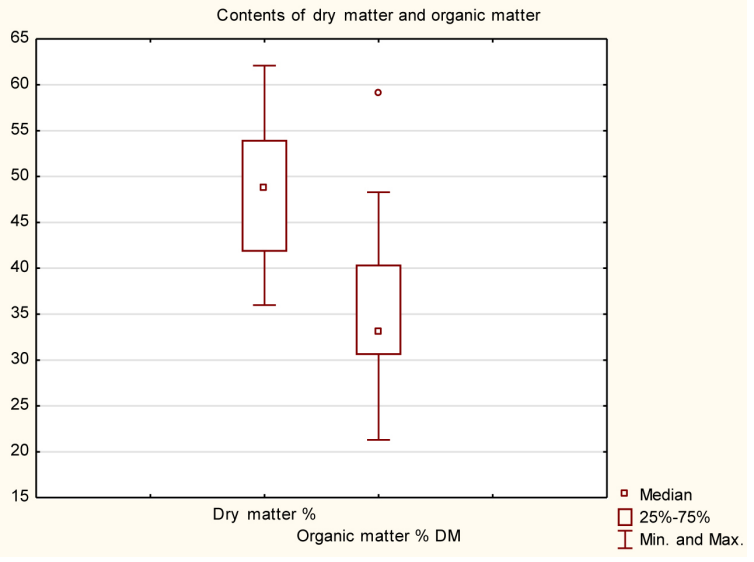

Figure 3. Contents of dry mass and organic substances on vermicompost

The process of sewage sludge vermicomposting using different species of earthworms is an alternative way of transforming waste into high quality and nutrient-rich fertilizer [Baran et al.1996, Kostecka et al. 1995 and 1996, Yadav et al. 2010, Boruszko 2011 and 2013b].

\section{CONCLUSIONS}

The conducted research on low-input methods of sewage sludge treatment in the vermicomposting process has resulted in the following achievements and practical conclusions:

- The conducted research allows to unequivocally state that the sewage sludge processed in the process of vermicomposting during the whole period of research, i.e. 16 years, meets the requirements of organic fertilizers in solid form [Regulation 2008]. Vermicomposts had a high content of organic matter (from $21.3 \%$ d.m. to $59.0 \%$ d.m.), nitrogen (from $0.98 \%$ d.m. to $3.11 \%$ d.m.), phosphorus (from $0.2 \%$ d.m. to $1.45 \%$ d.m.), well above the minimum values specified in the Regulation.

- According to the current Regulation of the Minister of the Environment on municipal sewage sludge [Regulation 2015] on the basis of which the verification for natural application is carried out, the vermicompost produced in the conducted research had concentrations definitely below the permissible limit values specified in the aforementioned Regulation. The heavy metal content was also significantly lower than the limit values specified in the Regulation of the Minister of Agriculture and Rural Development on the use of certain 
provisions of the Fertilizers and Fertilization Act [Regulation 2008], qualifying the tested vermicomposts for organic and organic-mineral fertilizers.

\section{Acknowledgment}

The study was conducted as a research project WZ/WBiIŚ/8/2019 in Faculty of Civil and Environmental Engineering at BUT and was financed by Ministry of Science and Higher Education.

\section{REFERENCES}

1. Alidadi H., Shamansouri A.P.M.; 2005. Combined compost and vermicomposting process in the treatment and bioconversion of sludge. Iranian Journal of Environmental Health Science \& Engineering, 2, 251-254.

2. Azizi, A.B., Lim, M.P., Noor, Z.M., Abdullah, N., 2013. Vermiremoval of heavy metal in sewage sludge by utilising Lumbricus rubellus. Ecotoxicol Environ Saf, 90, 13-20.

3. Bhatnagar, A., Kesari, K.K., Shurpali, N., 2016. Multidisciplinary Approaches to Handling Wastes in Sugar Industries. Water, Air, \& Soil Pollution, 227, 1-30.

4. Baran S., Pietrasik W., Zalewski P., Szczepankowska I., 1996. Przydatność wermikompostu z osadów ściekowych do rekultywacji i użyźniania gleb, Zeszyty Nauk AR w Krakowie, 47, 33-44.

5. Boruszko D. 2011. Badania i ocena wartości nawozowej kompostów i wermikompostów, Rocznik Ochrony Środowiska, 13 (2), 1417-1428.

6. Boruszko D., 2013. Impact low-cost processing methods On the contents of polycyclic aromatic hydrocarbons (PAHs) in sewage sludge, Ecological Chemistry and Engineering, 20, 9-10.

7. Boruszko D. 2013. Frakcjonowanie wybranych metali ciężkich w osadach ściekowych przetwarzanych metodami niskonakładowymi, Rocznik Ochrony Środowiska, 15, 1787-1803.

8. Boruszko D, Butarewicz A., 2015. Impact of Effective Microorganisms Bacteria on low-input sewage sludge treatment; Environmental Protection Engineering, 41 (4) 83-96.

9. Boruszko D., 2016 Determining the effectiveness in vermicomposting of sewage sludges and the attempt to increase the effectiveness by applying bacterial microorganisms, Journal of Ecological Engineering, 17 (3), 53-59.

10. Bożym M. 2012 Biologiczne przetwarzanie biodegradowalnej frakcji odpadów komunalnych i osadów ściekowych w wermikulturze. Prace
Instytutu Ceramiki i Materiałów Budowlanych, 10, 335-350.

11. Brown A. B., Mitchell M. J., 1981. Role of earthworm Eiseniafetida in affecting survival of Salmonella enteriditis se. typhimurium, Pedobiologia, 22, 434-437.

12. Butt, K.R., 1993. Utilisation of solid paper-mill sludge and spent brewery yeast as a feed for soildwelling earthworms. Bioresource Technology, 44, 105-107.

13. Dominguez, J., Edwards, C.A., 2011. Biology and Ecology of Earthworm Species Used for Vermicomposting, in: Clive A . Edwards, N.Q.A., Rhonda L. Sherman (Ed.), Vermiculture technology: earthworms, organic wastes, and environmental management. CRC Press USA.

14. Eastman, B.R., Kane, P.N., Edwards, C.A., Trytek, L., Gunadi, B., Stermer, A.L., Mobley, J.R., 2001. The effectiveness of vermiculture in human pathogen reduction for USEPA biosolids stabilization. Compost Science \& Utilization, 9, 38-49.

15. Edwards, C.A., Lofty, J.R., 1977. Examines the earthworm through morphology, taxonomy, biology and look at its environmental role, Biology of earthoworm. Chapman and Hall, London.

16. Hatanaka K., Ishioka Y., Furuichi E., 1983. Cultivation of EiseniafetidaRusing dairy waste sludge cake. W: "Earthworm ecology from Darwin to vermiculture", New York, 323-329.

17. Hoornweg, D., Bhada-Tata, P., 2012. What a waste: a global review of solid waste management.

18. Konopska K. 2011. Rola dżdżownic w środowisku i gospodarstwie domowym, Zielona Planeta, 1(94), 5-7.

19. Kasprzak K., 1994. Stan badań nad dżdżownicami Polski, Zesz. Nauk AR w Krakowie, 41, 25-49.

20. Kostecka J., 1995. Kompostowanie odpadów organicznych z udziałem dżdżownic, VIII Konferencja: „Problemy gospodarki wodno- ściekowej w regionach rolniczo- przemysłowych", Politechnika Białostocka, 288-296.

21. Kostecka J. 1997. Wermikultura w Polsce jako sposób zamiany osadu ściekowego w cenny nawóz organiczny. W: Materiały Międzynarodowej konferencji naukowotechnicznej nt. Osady ściekowe odpad czy surowiec? Wyd. Politechniki Częstochowskiej, 121-129.

22. Kostecka, J., 2000. Badania nad wermikompostowaniem odpadów organicznych. Zeszyty Naukowe Akademii Rolniczej w Krakowie. Rozprawy 268, 1-88.

23. Kostecka J., Kołodziej M., 1995. Niektóre cechy wermikompostu produkowanego przez dżdżownicę kompostową Eiseniafetida, Postępy Nauk Rolniczych, 2, 35-45. 
24. Kostecka J., Zamorska J., 1996. Zmiany wybranych cech osadów ściekowych pod wpływem obecności dżdżownic, Tom. Nauk. w Rzeszowie, Seria: Przyr. Podst. Prod. Roln., 3, 33-40.

25. Mitchell M.J., Mulligan R.M., Hartenstein R., Neuhauser E.F., 1977 conversion on sludges into "topsoils" by earthworms, Compost Science, 18, 28-32.

26. Morgan, J.E., Morgan, A.J., 1992. Heavy metal concentrations in the tissues, ingesta and faeces of ecophysiologically different earthworm species. Soil Biology and Biochemistry, 24, 1691-1697.

27. Neuhauser, E.F., Cukic, Z.V., Malecki, M.R., Loehr, R.C., Durkin, P.R., 1994. Bioconcentration and biokinetics of heavy metals in the earthworm. Environmental Pollution, 89, 293-301.

28. Ndegwa, P.M., Thompson, S.A., 2001. Integrating composting and vermicomposting in the treatment and bioconversion of biosolids. Bioresour Technol, $76,107-112$.

29. Lu, Y.-F., Lu, M., 2015. Remediation of PAHcontaminated soil by the combination of tall fescue, arbuscular mycorrhizal fungus and epigeic earthworms. Journal of hazardous materials, 285, 535-541.

30. Reynolds, J.W., Wetzel, M.J., 2004. Nomenclatura Oligochaetologica. Supplementum Quartum. A catalogue of names, descriptions and type specimens of the Oligochaeta. Illinois Natural History Survey Special Publication.

31. Riggle D. Holmes H., 1994. New horizons for commercial vermiculture, BioCycle- Journal of composting and recycling, 10, 58-62.

32. Rorat, A., Suleiman, H., Grobelak, A., Grosser, A., Kacprzak, M., Płytycz, B., Vandenbulcke, F., 2015. Interactions between sewage sludge-amended soil and earthworms-comparison between Eisenia fetida and Eisenia andrei composting species. Environ Sci Pollut Res, 1-10.

33. Rozporządzenie Ministra Rolnictwa i Rozwoju Wsi z dnia 18 czerwca 2008 r. w sprawie wykonania niektórych przepisów ustawy o nawozach i nawożeniu; Dz.U. 2008 nr 119 poz. 765.

34. Rozporządzenie Ministra Środowiska z dnia 1 sierpnia 2002 r. w sprawie komunalnych osadów ściekowych; Dz.U. 2002 nr 134 poz. 1140.

35. Rozporządzenie Ministra Środowiska z dnia 13 lipca 2010 r. w sprawie komunalnych osadów ściekowych; Dz.U. 2010 nr 137 poz. 924.

36. Rozporządzenie Ministra Środowiska z dnia 6 lutego 2015 r. w sprawie komunalnych osadów ściekowych; Dz.U. 2015 poz. 257.

37. Standard Methods for the Examination of Water and Wastewater, 21th ed., 2005 American Public Health Association/American Water Works Association/Water Environment Federation, Washington D.C., USA.

38. Suthar, S., Singh, S., 2008. Vermicomposting of domestic waste by using two epigeic earthworms (Perionyx excavatus and Perionyx sansibaricus). International Journal of Environmental Science and Technology 5, 99-106.

39. Walkowiak A., 2007. Effect of Selected Environmental Parameters on Sewage Sludge Vermicomposting". Polish Journal of Natural Sciences nr 22, 83-91.

40. Włóka, D., Kacprzak, M., Rosikoń, K., Fijałkowski, K., 2013. A study of the migration of polycyclic aromatic hydrocarbons (PAH's) in a sewage sludgesoil system. Environment Protection Engineering 39, 115-124.

41. Yadav, K.D., Tare, V., Ahammed, M.M., 2010. Vermicomposting of source-separated human faeces for nutrient recycling. Waste Manag 30, 50-56.

42. Yadav, K.D., Tare, V., Ahammed, M.M., 2012. Integrated composting-vermicomposting process for stabilization of human faecal slurry. Ecological Engineering 47, 24-29.

43. Yadav K.D., Gark V.K., 2010. Industrial wastes and sludges management by vermicomposting; Reviews in Environmental Science and Bio/ Technology, 10, 243-276. 